\title{
Microbial Bioformulations for Suppression of Major Insect Pests and Diseases and Enhanced Biochemical Properties of Tea Crop
}

\author{
Rituraj Deb $^{1}{ }^{*}$, L.C. Bora ${ }^{1}$ and P. Das ${ }^{2}$ \\ ${ }^{1}$ Department of Plant Pathology, Assam Agricultural University, Jorhat-785013, Assam, India \\ ${ }^{2}$ Department of Biochemistry and Agricultural Chemistry, Assam Agricultural University, \\ Jorhat-785013, India \\ *Corresponding author
}

\begin{tabular}{|c|c|}
\hline & A B S T R A C T \\
\hline & Four different microbial bioformulations (Bio \\
\hline Keywords & $\begin{array}{l}\text { were explored under a biointensive strategy for management of major insect pests (Tea } \\
\text { mosquito bug, Looper caterpillar, Red spider mites and Tea aphid) and disease (grey }\end{array}$ \\
\hline Bioformulation, & blight) of tea (Camellia sinensis). Analytical assays were also done to record biochemical \\
\hline $\begin{array}{l}\text { Biogreen-5, } \\
\text { Management, } \\
\text { Pest, Tea. }\end{array}$ & $\begin{array}{l}\text { changes in tea leaves due to application of the bioformulations following standard } \\
\text { protocol. The bioformulations were applied as foliar spray at an interval of } 15 \text { days during }\end{array}$ \\
\hline Article Info & red spider mite $(92.04 \%)$, looper caterpillar $(91.47 \%)$, aphid $(92.53 \%)$ and grey blight \\
\hline $\begin{array}{l}\text { Accepted: } \\
23 \text { April } 2017 \\
\text { Available Online: } \\
10 \text { May } 2017\end{array}$ & $\begin{array}{l}(91.20 \%) \text { was recorded due to application of Biogreen-5 (Trichoderma viride, } \\
\text { Pseudomonas fluorescens, Beauveria bassiana, Metarhizium anisopliae and Bacillus } \\
\text { thuringiensis based consortia bioformulation). Application of Biogreen-5 also showed } \\
\text { enhanced level of caffeine }(4.11 \%) \text { and polyphenols }(22.77 \%) \text { along with increase in the } \\
\text { green leaf yield }(7.80 \mathrm{~kg} / \mathrm{plot})\end{array}$ \\
\hline
\end{tabular}

\section{Introduction}

Tea (Camellia sinensis (L.) O. Kuntze) belonging to the family Theaceae and tribe Gordonaceae is a commercially grown, industry oriented evergreen crop. The crop is extensively cultivated in 13 states of India out of which Assam, West Bengal, Tamil Nadu and Kerala are the largest producers. Assam is the main tea growing state of India, mostly sub-Himalayan part of Assam from time immemorial. The total production of tea in Assam is 652.95 million kg per annum, which is more than 50 percent of India's total tea production (Anonymous, 2016). Tea is regarded as rich source of many beneficial properties such as stimulant, diuretic, digestive, anti aging, anti dysenteric, anti diarrhoea, slimming and as "summer heat and dampness". The chemical constituents present in tea includes, polyphenols, methylxanthines (caffeine, theophylline and theobromine), vitamins, amino acids, carbohydrates, proteins, chlorophyll, volatile compounds, fluoride, minerals, trace elements, and other undefined compounds (Cabrera et al., 2003). Altogether, 1034 species of arthropods, 82 species of nematodes, 1 algal disease and 350 fungal diseases are associated with tea plants resulting in significant yield loss (Chen and Chen, 1989), and only, 167 species have been recorded from North-East India (Das, 1965), 
resulting 11 - 30 per cent annual yield loss in general. Amongst the insect pests, tea mosquito bug [Helopeltistheivora (Waterhouse) (Hemiptera: Miridae)] has assumed the status of a major pest in several tea growing areas in West Bengal and Assam (Somchowdhury et al., 1993). The red spider mite, [Oligonychus coffeae (Nietner) (Acarina: Tetranychidae)] causes considerable crop losses in South India (Muraleedharan et $a l ., 2005)$ and at Terai, Dooars and Assam regions (Sharmah et al., 2009). Tea looper caterpillar, [Biston suppressaria (Guenee) (Lepidoptera: Geometridiae)] is a destructive and major defoliating pest of tea, shade trees and green crops (Ahmed and Mamun, 2010). Tea aphid, [Toxoptera aurantii (Hemiptera: Aphididae)] infestation also lead to poor crop productivity (Sohail et al., 2012). Among diseases, the grey blight disease of tea caused by Pestalotiopsis spp. has been reported from all tea-growing countries of the world (Venkata Ram, 1983).

In our present study attempts were made to explore some fungal and bacterial biocontrol agents with their consortium package for developing a biointensive management strategy against the major insect pests and diseases of tea.

\section{Materials and Methods}

Tea plants (TV-23 clone) from the Experimental Garden of Plantation crops, Assam Agricultural University, Jorhat, were used to study the efficacy of microbial bioformulation against the insect pests and disease (grey blight) during May to September of 2016. Four microbial bioformulations, viz., Biosona (Beauveria bassiana), Biotime (Metarhizium anisopliae, Pseudomonas fluorescens and Trichoderma harzianum), Biogreen-5 (powder formulation of T. viride, P. fluorescens, Bacillus thuringiensis, B. bassiana and M. anisopliae) and Biogreen-L (Liquid formulation of $T$. viride, $P$. fluorescens, $B$. thuringiensis, $B$. bassiana and $M$. anisopliae) and three chemicals viz., Spiromesifen, Clothianidin and Hexaconazole were used to evaluate their efficacy under field conditions. The bioformulations were collected from the Biocontrol Laboratory of Department of Plant Pathology, AAU, Jorhat and the chemicals were collected from the Experimental Garden of Plantation Crops, AAU, Jorhat.

The whole experimental area was laid out in RBD with five replications, five plots along with a control plot in each replication. Individual plots measured $5 \mathrm{~m} \times 3 \mathrm{~m}$. Between each replication, $1.5 \mathrm{~m}$ of distance was maintained.

Each plot approximately contained 60 numbers of tea bushes. The treatment combinations compared were, foliar spray of Biosona (2.0\%), Biotime (2.0\%), Biogreen-5 (2.0\%), Biogreen-L (2.0\%), three chemicals, viz., Oberon (Spiromesifen 22.9\% EC) @ 0.05\%, Dantotsu (Clothianidin 50\% WDG) @ $0.25 \%$ and Sitara (Hexaconazole 5\% EC) @ $0.25 \%$. The control plants were sprayed with distilled water only. Altogether 10 sprays were done at an interval of 15 days from May-September, 2016 with manually operated hydraulic Knapsack sprayer.

For record of Tea mosquito bug incidence, 10 plants were randomly selected and thirty leaf samples were collected (3 samples/plant) from each plot. The incidence of tea mosquito bug was recorded in 0 to 4 scale of Jalgaonkar et al., (2009). The data so obtained was converted into per cent mosquito bug incidence.

For record of red spider mites, looper and aphid, the infested leaves and total leaves from 10 randomly selected plants were recorded in each treated and untreated plot and percentage incidence was calculated. 
Grey blight disease incidence was recorded directly on the bush canopy using a quadrate of 1 sq. ft. size placing over the plucking table at random bushes. The number of infected and uninfected intact leaves, cut leaves, bare stalks and young shoots in $1 \mathrm{sq}$. ft. area were counted and the percentage were individually calculated. The disease reduction was calculated with the following standard formula: Disease reduction $(\%)=100-$ Disease Incidence.

\section{Biochemical analysis}

Caffeine content of leaf was estimated by the method of Yao et al., 2006. The caffeine per cent in leaves were calculated by using the formula:

Caffeine $(\%)=E / 1000 \times \mathrm{V}_{0} \mathrm{x}\left(100 / \mathrm{V}_{1}\right) \mathrm{x}$ $(50 / 25) / \mathrm{W}=0.2 \mathrm{EV}_{0} / \mathrm{V}_{1} / \mathrm{W}$; where $\mathrm{E}$ is $\mathrm{mg}$ of caffeine from the standard curve against the reading of the spectrophotometer, and E/1000 is to convert ' $\mathrm{mg}$ ' into ' $\mathrm{g}$ '; $\mathrm{V}_{0}$ is the total volume of the tea solution $(250 \mathrm{ml}) ; \mathrm{V}_{1}$ is the volume used for the measurement $(10 \mathrm{ml})$, and $100 / \mathrm{V}_{1}$ indicates $10 \mathrm{ml}$ tea solution that were diluted to $100 \mathrm{ml}$, while 50/25 shows that another dilution from $25 \mathrm{ml}$ tea filtrate madeto $50 \mathrm{ml}$ in the measurement. ' $\mathrm{W}$ ' is the dry weight of the tea sample.

Total polyphenol was estimated by Folinciocalteu method (Bray and Thorpe, 1954). For yield assessment, weight of green leaves harvested in each plucking round was recorded for individual plot and the monthly total was calculated.

For statistical analysis, the data of per cent values were transformed into corresponding angular values or log values wherever necessary. To compare the different treatments among themselves, critical differences were calculated out.

\section{Results and Discussion}

\section{Efficacy of different microbial bioformulations in reduction of major insect pests and diseases of tea}

All the treatments showed different degree of efficacy in controlling the insect pest as well as disease infestation as compared to control. The incidence of the pest was higher during the early part of May and as such, first spray was made during $1^{\text {st }}$ week of May'2016 $\left(1^{\text {st }}\right.$ May' 2016). The remaining nine sprays were made at an interval of 15 days following the $1^{\text {st }}$ spray. The last spray was made on 15 th Sept' 2016. The effect of standard chemical check seems to be highest but was significantly at par with the effect of bioformulation Biogreen-5. Lowest incidence of Tea mosquito bug (7.24\%), Red spider mite (6.17\%), Looper caterpillar (6.16\%), Aphid $(0.0 \%)$ and Grey blight $(4.86 \%)$ was recorded after application of 10 sprays of Biogreen-5 (2.0\%). Other bioformulation treatments, i.e., Biosona, Biotime, Biogreen-L could control the insect pest and disease damage but their efficacy was lower as compared to Biogreen-5. Effect of different microbial bioformulations on incidence of tea mosquito bug, Red spider mite, Looper caterpillar, aphid, grey blight is presented in table 1.

PGPM formulation has been earlier tried for controlling various fungal and bacterial pathogens (Nandakumar et al., 2001) which has provided an important clue of the commercial potential of the PGPR strains as well as commercialization of many microbial biocontrol products. Ramamoorthy et al., (2001) has reported that several crop diseases and insect pests could be managed by use of talc-based microbial bioformulation. In addition to disease management, the PGPR strains has also been proved to increase plant 
growth and yield of various crops viz., rice, potato, radish, mango and sugarbeet (Vivekananthan et al., 2004). Our record showed that consortia of $P$. fluorescens, $T$. viride, B. thuringiensis, B. bassiana and $M$. anisopliae could significantly decrease pest and pathogen of tea along with increase in the yield. Reddy et al., (2001), observed that foliar spray of powder formulations of PGPR strains could promote the plant growth besides effectively controlling tomato bacterial spot (Xanthomonas axonopodis pv. vesicatoria), cucumber angular leaf spot (Pseudomonas syringae pv. lachrymans), tobacco blue mold (Peronospora tabacina) and wild fire $(P$. syringae pv. tabaci). In China, B. bassiana was used to control pests of tea, brown weevil (Myllocerus aurolineatus) successfully (Wu and Sun, 1994). Wu et al., (1995) sprayed $15-30 \mathrm{~kg}$ of the fungus@1-2 x10 $0^{8}$ spores $/ \mathrm{ml}$ suspension and recorded 80 per cent control of the weevil in the field. Formulation of this fungus was prepared in order to apply it in combination with synthetic pyrethroid and organophosphorous insecticides for controlling $M$. aurolineatus during October December, a period when adults emerge from the soil (Sun et al., 1993). Barua (1983) reported the occurrence of Aspergillus sp. on dead aphids collected from the tea plantation. The potentiality of utilizing Verticillium lecanii, B. bassiana, Aegertia weberri and Entomophthora sp. against scale insects was also reported by Hazarika et al., (1994). They sprayed water extract of plant products along with Metarhizium anisopliae and obtained good control of red spider mite.

\section{Efficacy of different microbial bioformulations on yield $(\mathrm{kg} / \mathrm{plot})$ of green tea leaves}

The data on green leaf yield of tea as influenced by different bioformulation treatments are also presented in table 1 . There was a significant increase in the yield of green leaf in all the treatments as compared to the untreated control. The highest yield (7.80 $\mathrm{kg} / \mathrm{plot}$ ) was recorded in the plot treated with Biogreen-5. Among all treatments, lowest yield was recorded in the plot treated with Biogreen-L $(3.73 \mathrm{~kg} / \mathrm{plot})$.

The decrease in the pest incidence and increase in the yield of tea might be due to suppression of the pest population by application of microbial bioformulation of different bioactive micro-organism. The present study also shows that there was significant reduction in insect pest and grey blight incidence in tea plants. Similar findings were also reported by Sravanakumar et al. (2007) that bioformulation of $P$. fluorescens and $B$. thuringiensis at weekly spray intervals consistently reduced the blister blight as well as grey blight disease incidence and increased the yield in tea plants.

Effect of different microbial bioformulations in caffeine and polyphenol content of tea leaves

The data of biochemical analysis (caffeine and polyphenol) are presented in table 2 . There was a significant increase in the caffeine and polyphenols content of tea leaves in the treated plots as compared to the control (Fig. 1). Highest caffeine $(4.11 \%)$ and polyphenols (22.77\%) content was assayed in the leaves of plots treated with Biogreen-5, which was comparatively more than the standard chemical check with caffeine (3.74\%) and polyphenol (19.20\%) respectively. Assay of tea leaves treated with other bioformulation treatments, i.e., Biosona, Biotime, Biogreen-L showed standard concentration of caffeine as well as polyphenol, but was comparatively lower than treatment with Biogreen-5. Sudhakaran et al., (2000) studied the influence of tea mosquito bug infestation on biochemical constituents of 
green leaf and quality parameters of black tea. Biochemical constituents such as chlorophyll, carotenoids, polyphenols, total sugars were very much reduced when the plants are severely affected. Kumaravadivelu et al., (1996) also reported a reduction in biochemical constituents of tea leaves due to flush worm infestation. Sanjay et al., 2007 reported that biochemical constituents like polyphenols and catechins were highly reduced due to Pestalotiopsis infection in tea leaves. Mamun et al., (2016), reported that there was a reduction in chlorophyll as well as polyphenol contents of tea leaves due to infestation of red spider mites. In our study we also recorded a reduction of biochemical constituents (polyphenols and caffeine) of the young tea leaves due to insect pest and disease infestation.

Table.1 Effect of different microbial bioformulations on incidence of tea mosquito bug, red spider mite, looper caterpillar, aphid, grey blight and yield (kg/plot) of tea

\begin{tabular}{|c|c|c|c|c|c|c|}
\hline \multirow{2}{*}{ Treatment } & \multicolumn{6}{|c|}{$\begin{array}{c}\text { Percent incidence of insect pests, disease and yield of tea plant after } 10 \\
\text { sprays of bioformulations at } 15 \text { days interval }\end{array}$} \\
\hline & $\begin{array}{c}\text { Tea } \\
\text { mosquito } \\
\text { bug }\end{array}$ & $\begin{array}{l}\text { Red } \\
\text { spider } \\
\text { mite }\end{array}$ & $\begin{array}{c}\text { Looper } \\
\text { caterpillar }\end{array}$ & Aphid & $\begin{array}{c}\text { Grey } \\
\text { blight }\end{array}$ & $\begin{array}{c}\text { Yield } \\
\text { (Kg/plot) }\end{array}$ \\
\hline Biosona (2\%) & $\begin{array}{c}35.85 \\
(36.75)^{\mathrm{b}}\end{array}$ & $\begin{array}{c}34.11 \\
(35.73)^{\mathrm{b}}\end{array}$ & $\begin{array}{c}30.23 \\
(33.34)^{b}\end{array}$ & $\begin{array}{c}10.36 \\
(18.81)^{b}\end{array}$ & $\begin{array}{c}79.54 \\
(63.05)^{\mathrm{b}}\end{array}$ & $\begin{array}{c}4.77 \\
(12.66)^{\mathrm{b}}\end{array}$ \\
\hline Biotime $(2 \%)$ & $\begin{array}{c}13.82 \\
(21.81)^{\mathrm{c}}\end{array}$ & $\begin{array}{c}21.33 \\
(27.49)^{\mathrm{c}}\end{array}$ & $\begin{array}{c}14.61 \\
(22.46)^{\mathrm{c}}\end{array}$ & $\begin{array}{c}7.82 \\
(16.22)^{\mathrm{c}}\end{array}$ & $\begin{array}{c}21.03 \\
(27.27)^{\mathrm{c}}\end{array}$ & $\begin{array}{c}6.32 \\
(14.54)^{\mathrm{c}}\end{array}$ \\
\hline Biogreen-5(2\%) & $\begin{array}{c}7.24 \\
(15.56)^{d}\end{array}$ & $\begin{array}{c}6.17 \\
(14.42)^{\mathrm{d}}\end{array}$ & $\begin{array}{c}6.16 \\
(14.42)^{\mathrm{cd}}\end{array}$ & $\begin{array}{c}0.00 \\
(0.00)^{\mathrm{d}}\end{array}$ & $\begin{array}{c}4.86 \\
(12.79)^{\mathrm{d}}\end{array}$ & $\begin{array}{c}7.80 \\
(16.22)^{\mathrm{d}}\end{array}$ \\
\hline $\begin{array}{l}\text { Biogreen-L } \\
(2 \%)\end{array}$ & $\begin{array}{c}47.44 \\
(43.51)^{\mathrm{e}}\end{array}$ & $\begin{array}{c}58.57 \\
(49.95)^{\mathrm{e}}\end{array}$ & $\begin{array}{c}48.25 \\
(44.03)^{\mathrm{e}}\end{array}$ & $\begin{array}{c}22.53 \\
(28.32)^{\mathrm{e}}\end{array}$ & $\begin{array}{c}33.94 \\
(35.67)^{\mathrm{ce}}\end{array}$ & $\begin{array}{c}3.73 \\
(11.09)^{\mathrm{e}}\end{array}$ \\
\hline $\begin{array}{c}\text { Clothianidin } \\
(0.05 \%), \\
\text { Spiromesifen } \\
(0.25 \%) \& \\
\text { Hexaconazole } \\
(0.25 \%)\end{array}$ & $\begin{array}{c}3.62 \\
(10.94)^{\mathrm{df}}\end{array}$ & $\begin{array}{c}3.29 \\
(10.47)^{\mathrm{df}}\end{array}$ & $\begin{array}{c}5.11 \\
(13.05)^{\mathrm{df}}\end{array}$ & $\begin{array}{c}0.00 \\
(0.00)^{\mathrm{df}}\end{array}$ & $\begin{array}{c}4.29 \\
(11.97)^{\mathrm{df}}\end{array}$ & $\begin{array}{c}7.04 \\
(15.34)^{\mathrm{cdf}}\end{array}$ \\
\hline Control & $\begin{array}{c}96.30 \\
(78.91)^{\mathrm{a}}\end{array}$ & $\begin{array}{c}98.21 \\
(82.29)^{\mathrm{a}}\end{array}$ & $\begin{array}{c}97.63 \\
(81.09)^{\mathrm{a}}\end{array}$ & $\begin{array}{c}92.53 \\
(74.11)^{\mathrm{a}}\end{array}$ & $\begin{array}{c}96.06 \\
(78.46)^{\mathrm{a}}\end{array}$ & $\begin{array}{c}0.63 \\
(4.44)^{\mathrm{a}}\end{array}$ \\
\hline SEd & 2.71 & 3.90 & 4.41 & 0.51 & 4.30 & 0.51 \\
\hline CD (0.05) & 5.64 & 8.15 & 9.21 & 1.06 & 8.98 & 1.06 \\
\hline
\end{tabular}

Values in the parenthesis are angular transformed values

Values superscripted with same letters are not significantly different $(\mathrm{P}=0.05)$

Observations are mean of five replications 
Table.2 Effect of different microbial bioformulations in caffeine (\%) and polyphenol(\%) content of green tea leaf

\begin{tabular}{|c|c|c|}
\hline \multirow[t]{2}{*}{ Treatment } & \multicolumn{2}{|c|}{$\begin{array}{l}\text { Biochemical parameters of tea leaves treated with } \\
\text { microbial bioformulation }\end{array}$} \\
\hline & Caffeine (\%) & Polyphenols (\%) \\
\hline Biosona (2\%) & $\begin{array}{c}2.20 \\
(8.53)^{b}\end{array}$ & $\begin{array}{c}12.35 \\
(20.62)^{b}\end{array}$ \\
\hline Biotime $(2 \%)$ & $\begin{array}{c}2.84 \\
(9.63)^{\mathrm{c}}\end{array}$ & $\begin{array}{c}17.34 \\
(24.58)^{\mathrm{c}}\end{array}$ \\
\hline Biogreen-5 (2\%) & $\begin{array}{c}4.11 \\
(11.68)^{d}\end{array}$ & $\begin{array}{c}22.77 \\
(28.52)^{d}\end{array}$ \\
\hline Biogreen-L (2\%) & $\begin{array}{c}1.82 \\
(7.71)^{\mathrm{e}}\end{array}$ & $\begin{array}{c}10.62 \\
(19.00)^{b}\end{array}$ \\
\hline $\begin{array}{l}\text { Clothianidin }(0.05 \%), \\
\text { Spiromesifen }(0.25 \%) \& \\
\text { Hexaconazole }(0.25 \%)\end{array}$ & $\begin{array}{c}3.74 \\
(11.09)^{\mathrm{df}}\end{array}$ & $\begin{array}{c}19.20 \\
(25.99)^{\text {cde }}\end{array}$ \\
\hline Control & $\begin{array}{c}0.94 \\
(5.44)^{\mathrm{a}}\end{array}$ & $\begin{array}{c}6.36 \\
(14.65)^{\mathrm{a}}\end{array}$ \\
\hline SEd & 0.35 & 1.69 \\
\hline $\mathrm{CD}(0.05)$ & 0.72 & 3.41 \\
\hline
\end{tabular}

Values in the parenthesis are angular transformed values

Values superscripted with same letters are not significantly different $(\mathrm{P}=0.05)$

Observations are mean of five replications

Fig.1 Caffeine and Polyphenol content in tea (TV 23) clones treated with different microbial formulation

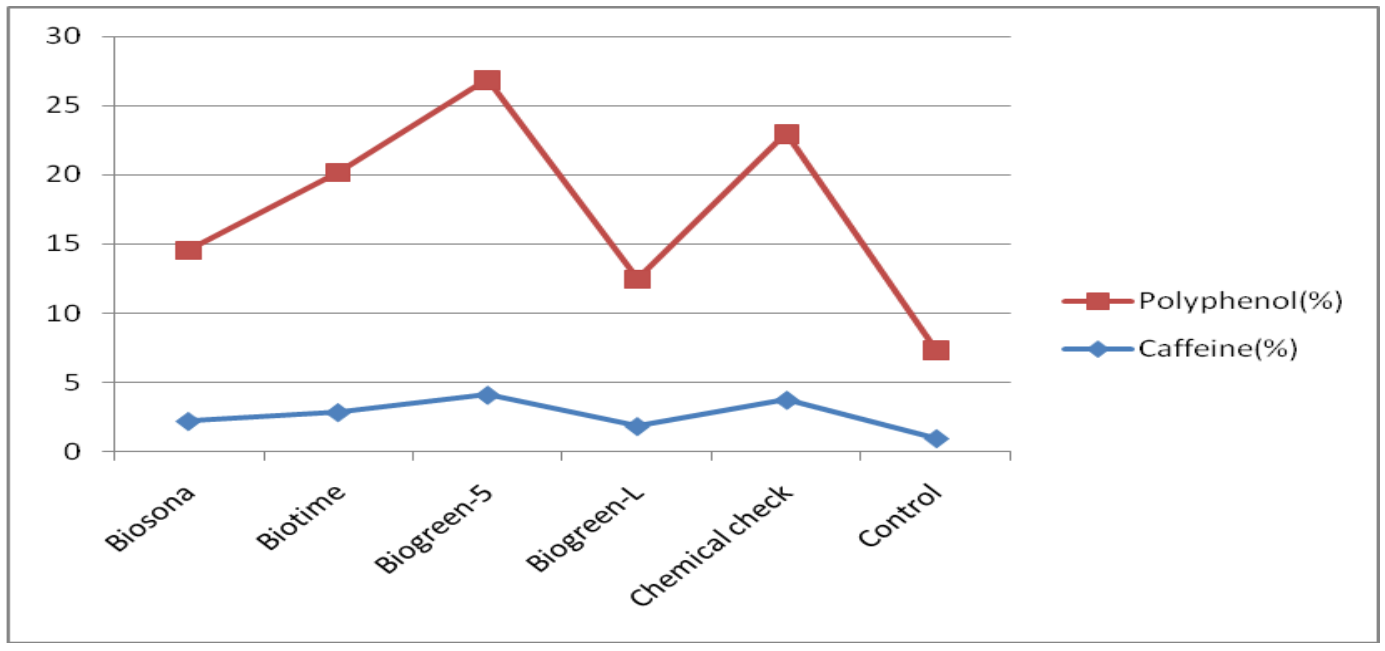


However, there was a significant decrease in the pest and disease infestation along with increase in the level of these biochemical constituents when the crop was treated with different microbial bioformulations, depicting that major foliar diseases and insect pests of tea can be controlled up to a desired level by application of microbial bioformulations. Application of microbial bioformulations as foliar spray can also help in minimizing the chemical pesticides load on tea. As tea consumption is gaining popularity throughout the world, more emphasis should be given in the production of quality tea with standard biochemical compounds as well as better agronomical characteristics for successful cultivation and commercialization.

\section{Acknowledgements}

Authors are sincerely thankful to the Department of Tea Husbandry and Technology and Department of Biochemistry and Agricultural Chemistry, Assam Agricultural University for providing necessary facilities to conduct the different experiments. The authors also acknowledge the DBT-AAU Centre, AAU, Jorhat for providing laboratory facilities to carry out different analytical works.

\section{References}

Ahmed, M. and Mamun, M.S. 2010. Looper caterpillar- a threat to tea and its management. Circular No.-132. Bangladesh Tea Research Institute.

Anonymous.2016.http://www.teaboard.gov.in/pdf /Press_realease_India_records_highest_eve r_tea_production_during.pdf

Barua, G.C.S. 1983. Fungi in biological control of tea pest and disease in Northeast India. Two and $a$ Bud. 30: 5-7.

Bray, H. G. and Thorpe, W. V. 1954. Analysis of phenolic compounds of interest in metabolism. Methods of Biochemical Analysis. 52: 1-27.

Cabrera, C., Gimenez, R. and Lopez, C. 2003.
Determination of tea components with antioxidant activity. J. Agric. Food Chem. 51: 4427-35.

Chen, Z.M. and Chen, X.F. 1989. An analysis of world tea pest fauna. J. Tea Sci. 9: 13-22.

Das, G.M. 1965. Pests of tea in North East India and their control. Memorandum No. 27. Indian Tea Association, Tocklai Experimental Station, Jorhat, Assam. India. pp. $169-173$

Hazarika, L.K., Puzari, K.C. and Barua, G. 1994. Fungi as microbial insecticides on mole cricket. Two and a Bud 41 (2): 22-25.

Jalgaonkar, V. N., Gawankar, M. S., Bendale, V. W. and Patil, P. D. 2009. Efficacy of some insecticides against cashew tea mosquito bug Helopeltis antonii Sign. J. Plant Prot. Sci. 1(1): 96-97.

Kumaravadivelu, P., Radhakrishnan, B. and Muraleedharan, N. 1996. Studies on flushworm (Cydialeu costoma Meyrick) tea plant interactions. J. Plant. Crops. 24: 309-318.

Mamun, M.S., Hoque, M., Ahmed, M. and Yasin, M. 2016. Physiological and Biochemical Changes in Tea Leaves and Made Tea Due to Red Spider Mite Infestation. Asian J. Plant Sci. 15: 16-25.

Muraleedharan, N., Sudarmani, D.N.P. and Selvasundaram, R. 2005. Bioecology and management of the red spider mite infesting tea in south India. In: Proceedings of International Symposium on Innovation in tea science and sustainable development in tea industry. China tea science Society, Hangzhou, China, pp-756-766.

Nandakumar, R., Babu, S., Viswanathan, R., Raguchander, T. and Samiyappan, R. 2001. Induction of systemic resistance in rice against sheath blight disease by plant growth promoting rhizobacteria. Soil Biol. Biochem. 33: 603-612.

Ramamoorthy, V., Viswanthan, R., Raguchander, T., Prakasam, V. and Samiyappan, R. 2001. Induction of systemic resistance by plant growth promoting rhizobacteria in crop plants against pest and diseases. Crop Prot. 20: $1-11$.

Reddy, M.S., Ryu, C.M., Zhang, S., Yan, Z. and Kloepper, J.W. 2001. Aqueous formulations of plant growth-promoting 
rhizobacteria for control of foliar pathogens. Phytopathology. 91: 79-85.

Sanjay, R., Ponmurugan, P. and Baby, U.I. 2007. Evaluation of fungicides and biocontrol agents against grey blight disease of tea in the field. J. Plant. Crops. 24: 249-255

Saravanakumar, D., Vijayakumar, C., Kumar, N. and Samiyappan, R. 2007. PGPR-induced defense responses in the tea plant against grey blight and blister blight disease. Crop Prot. 26: 556-565.

Sharmah, M., Rahman, A., Phukan, A.K. and Gurusubramanian, G. 2009. Effect of aqueous plant extracts on tea red spider mite, Oligonychys coffeae, Nietner (Acarina: Tetranychidae) and Stethorus gilvifrons Mulsant. Afr. J. Biotechnol. 8(3):417-423

Sohail, A., Hamid, F.S., Waheed, A., Ahmed, N., Aslam, N., Zaman, Q., Ahmed, F. and Islam, S. 2012. Efficacy of different botanical Materials against Aphid Toxoptera aurantii on tea (Camellia sinensis L.) cuttings under high shade nursery. J. Mater. Environ. Sci. 3(6): 10651070.

Somchoudhury, A.K., Samanta, A.K. and Dhar, P.P. 1993. Approaches to integrated control of tea mosquito bug. Proceedings of International Symposium. Calcutta, pp. 330-338

Sudhakaran, R., Selvasundaram, R. and Muraleedharan, N. 2000. Physiological and biochemical changes in tea leaves due to mosquito bug infestation. In: Muraleedharan, N., and Rajkumar, R.
[Eds.] Recent Advances in Plant Science Research. Allied Publishers, New Delhi, India. pp. 282-292.

Sun, J. D., Wu, G.Y., Lin, A., Zeng, M.S., Wang, Q.S. and Xu, D.Y. 1993. Investigation and demonstration of the integrated control of the tea weevil by a mixture of pesticides and microbes. Tea Sci. Tech. Bull. 3: 32-34.

Venkata Ram, C.S. 1983. Pathogens and pests of tea. In: Exotic Plant Quarantine Pests and Procedures for Introduction of Plant Materials, UPASI Scientific Department, Coonoor, India, pp: 117-44.

Vivekananthan, R., Ravi, M., Ramanathan, A. and Samiyappan, R. 2004. Lytic enzymes induced by Pseudomonas fluorescens and other biocontrol organisms mediate defence against the anthracnose pathogen in mango. World J. Microbiol. Biotechnol. 20: 235244.

Wu, G.Y. and Sun, J. D. 1994. A study and application of Beauveria bassiana (Bals) Vuill. in the control of the tea brown weevil. China Tea. 16 (1): 30-31.

Wu, G. Y., De, S. J., Shen, Z. M., Aug, L. A., Yean, X.D., and Shen. W. Q. 1995. Application of Beauveria bassiana strain 871 in controlling tea weevil (Myllocerus aurolineatus). J. Fujian Acad. Agric. Sci. 10 (2): 39-43.

Yao, L., Liu, X., Jiang, Y., Caffin, N., Arcy, B.D., Singanusong, R., Datta, N., and $\mathrm{Xu}, \mathrm{Y}$. 2006. Compositional analysis of teas from Australian supermarkets. Food Chem. 94: $115-122$.

\section{How to cite this article:}

Rituraj Deb, L.C. Bora and P. Das. 2017. Microbial Bioformulations for Suppression of Major Insect Pests and Diseases and Enhanced Biochemical Properties of Tea Crop. Int.J.Curr.Microbiol.App.Sci. 6(5): 1872-1879. doi: https://doi.org/10.20546/ijcmas.2017.606.218 